\title{
Potential Effect of Dietary Vitamins A, C, and E, their Levels in Serum within Asthmatic Children
}

\author{
Gihan F Ahmad ${ }^{1}$, Hala M Abdel-salam ${ }^{2}$, Naglaa M Abd Alfattah ${ }^{1}$ and Magda \\ R Kostandy ${ }^{1}$
}

1. Nutritional Requirement and Growth department - National Nutrition Institute - Cairo Egypt

2. Outpatient laboratory-National Nutrition Institute - Cairo Egypt

Corresponding Author: Hala M Abdel-salam, professor of Clinical pathology, head of outpatient laboratory, National Nutrition Institute Tel.: (+2) 01066737963 Email: hlsalam@yahoo.com

\section{SUMMARIZED}

$T$ he respiratory allergic ailment is an inflammatory condition joined by oxidative stress. Extra elements of anti-inflammatory factors such as antioxidants may have a curative effect. This study planned the status of vitamins $(A, E \& C)$ in food and sera of young some Egyptian children with allergic asthma coming to the National Nutrition Institute (NNI). The study inclsive104 children who attended the pediatric outpatient clinic of NNI during August and September 2014. The subjects in the study, both boys and girls, were randomly selected within the age range from 7-10 years. Asthma signs were assessed by a Chinese version of the International Study of Asthma and Allergies in Childhood (ISAAC) questionnaire. Data on nutritional status had been collected using specially designed questionnaires to cover required information on food intake (24-hour recall) and dietary pattern (food frequency) for chosen items. Body mass index was calculated based on the bodyweight within kilograms divided by the square of the body height in meters. After an overnight fast of 12 hours, blood samples of $5 \mathrm{ml}$ were collected from the children to determine serum levels of vitamin $A, E$, and $C$. The outcome revealed decreased daily intake and serum content from vitamin $A, E$, and $C$ within asthmatic children parallel to normal children. Conclusion Despite the low level of intake antioxidants or there in serum within asthmatic children with no significant differences, they had signs of asthma, which confirms that the decrease in these vitamins, even a small amount, leads to asthma sensitivity.

Key words: Asthma-Antioxidant - Children 


\section{INTRODUCTION}

Asthma is defined as a morbidness of the airways. Inveterate inflammation is expounded to airway hyper-responsiveness that ends up in repeated episodes of breathlessness, chest tightness, sound within the chest, or coughing, which is able to vary over time and in adversity. Symptom episodes either are generally associated with widespread, but variable, airflow obstruction within the lungs that is usually reversible spontaneously or with appropriate asthma treatment sort of a fast-acting bronchodilator (GINA, 2017). Asthma diseases have increased prevalence. Despite decades of research on risk factors, the causes of those disorders are poorly understood. They are thought to develop through complex interactions between genetic and environmental factors (MorenoMacias and Romieu 2014). Asthma could be a common and potentially serious chronic disease that imposes a considerable burden on patients, their families, and therefore the community. It causes respiratory symptoms, limitation of activity, and flare-ups (attacks) that sometimes require urgent health care and perhaps fatal (Pedersen et al., 2018). Asthma is characterized by recurrent attacks of dyspnea, cough, expectoration of tenacious mucoid sputum, and frequently wheezing. Symptoms could also be mild and will occur only in association with a respiratory tract infection, or they will occur in various degrees of severity to the purpose of being life threatening. Classic asthma usually begins in childhood and becomes progressively more severe throughout life. The acute attack is characterized by dyspnea usually related to expiratory wheezing that will be heard without a stethoscope. Cough is also present but is sometimes not the predominant symptom (Federico et al., 2016). Asthma could also be a chronic disease requiring ongoing and comprehensive treatment goals to chop back the symptom burden (i.e. good symptom control while maintaining normal activity levels) and minimize the possibility of adverse events like exacerbations, fixed airflow limitation, and treatment side effects (GINA, 2019).

Vitamin A is a group of chemical substances - retinoid, fatsoluble compounds essential for the human body. It cannot be produced and have to be provided as a part of the diet. In animal origin food, it is present in ester form as retinyl palmitate, which is converted in the human body to alcohol - retinol. In a plant-based diet, 
it is present in form of $\beta$-carotene, $\beta$ cryptoxanthin, and other carotenoids (Shmarakov et al., 2013). The function of vitamin $\mathrm{A}$ is its role in the vision cycle (Kiser et al., 2014), regulatory and promoting effects on the immune system, a valuable enhancer of immunity against numerous infectious diseases and pathologies (Huang et al., 2018). Both the $T$ cell-mediated and antibody-dependent immune responses are affected by this vitamin, which is relevant in the process of synthesis of immunoglobulins A and E (Pantazi et al., 2015). Retinoid also has repressive activity on $\mathrm{IgE}$; therefore, they may ameliorate allergic diseases mediated by IgE (Heine et al., 2018, Seo et al., 2017). Vitamin A has to a certain degree, a therapeutic effect in diseases transmitted through the respiratory system, e.g. measles, infantile diarrhea, or pneumonia in children (Hu et al., 2018).

Vitamin $\mathrm{C}$ can act as a hydrogen donor to reverse oxidation and therefore functions as an antioxidant that reacts with free radicals (FRs) and deactivates them before they cause damage to proteins or lipids (Hacışevki, 2009). Vitamin C (ascorbic acid) is an important antioxidant and thus works in aqueous environments of the body. Vitamin $\mathrm{C}$ cooperates with Vitamin $\mathrm{E}$ to regenerate $\alpha$-tocopherol from atocopherol radicals in membranes and raises glutathione levels that is playing a role in the thiol group protection versus oxidation (Kojo, 2004). Oxygen metabolites may play direct and indirect roles in the modulation of airway inflammation (Shanmugasundaram et al., 2001). Vitamin $C$ works in enzyme activation, oxidative stress decrease, and immune tasks. There is considerable evidence that vitamin $\mathrm{C}$ may protect against respiratory tract infections and reduce the risk for cardiovascular disease and some cancers (Schlueter and Johnston, 2011).

Vitamin $\mathrm{E}$ is the most abundant lipid-soluble antioxidant present in body tissues (Zingg, 2015). Intake antioxidants have a beneficial effect on the prevention and management of chronic diseases (Cheng, et al., 2018, Amanullah et al., 2019). Vitamin E consists of substances belonging to two closely related groups: tocopherols and tocotrienols, each existing in four isomeric forms, $\alpha, \beta, \gamma$ and $\delta$ making 8 different group members. The biological potency accounting for $90 \%$ of the vitamin activity in tissues is $\alpha$ tocopherol (Rock et al., 2001). Vitamin $\mathrm{E}$ is the major lipid-soluble component in the cell antioxidant 
defense and is exclusively obtained from the diet. It has numerous roles within the body because of its antioxidant activity (Rizvi et al., 2014).

The present study goal to investigate the relationship between the intake of natural antioxidants and incidence of asthma.

\section{SUBJECTS AND METHODS}

The Research Ethics Committee at National Nutrition Institute (NNI) approved this cross-sectional study.

\section{Subjects}

The study included 104 children from both sexes who attended the pediatric outpatient clinic of NNI during August and September 2014. They were randomly selected in the age range from 7-10 years. A face-toface interview was completed with the attending parents. Informed consent was obtained from the parents of the children in the study.

\section{Methods:}

Asthma symptoms assessment:

Asthma symptoms were assessed using a Chinese version of the International Study of Asthma and Allergies in Childhood (ISAAC) questionnaire (Asher et al, 1995).
Asthma symptoms were defined in the following cases:

a) when there were wheezing attacks more than one time during the last 12 months,

b) when there were $\geq 4$ wheezing attacks in the last 12 months,

c) when sleep was disturbed $\geq 1$ night/per week,

d) when dyslogia occurred due to wheezing in the last 12 months.

e) if there was dry cough at night, apart from a cough associated with a cold or a chest infection during the last 12 months

f) if there was wheezing during or after exercise during the last 12 months

$\mathrm{g}$ ) if there was a positive answer to the question "Has your child ever had asthma?"

According to (ISAAC) questionnaire the children involved in the study were divided into normal children with no asthmatic symptoms $(\mathrm{N}=61)$ and asthmatic children $(\mathrm{N}=43)$ showing one or more of the abovementioned symptoms.

Assessment of non-dietary information:

Information on children's characteristics, age, sex, and parental education level, and parental asthma history, number of siblings, and vigorous exercise (that produces sweating) was obtained from parents 
using a demographic questionnaire. Parental asthma history was defined as a reported history of clinicallydiagnosed asthma in one or more parents. The vigorous sweat-inducing exercise was defined as performing an exercise that induced sweating more than three times a week.

\section{Dietary assessment:}

Data on nutritional status had been collected using specially designed questionnaires to cover required information on food intake (24-hour recall) and dietary pattern (food frequency) for selected items.

\section{a) Food intake:}

Using the 24-hour recall method, detailed food intake for each eating event was obtained during the previous day to the interview, starting with the first eating event (breakfast) and continuing with each eating event subsequently until before sleep. Amounts of foods and beverages consumed were determined by using dietitian equipment, utensils of known weights, and volumes.

\section{b) Food frequency method:}

This method was used to obtain a profile of food intake for the study group. A questionnaire was designed to cover the selected food items on daily, weekly and monthly basis.

The chosen nutrient content of the last 24 hour was computed using the compiled food composition tables of the National Nutrition Institute, (NNI, 2006). The nutritional value of foods and beverages consumed was compared to the recommended dietary allowances "RDAs" of WHO.FAO. /UNU) (Gibson, 1990) and were considered as cut off points for micronutrients.

\section{Anthropometric Measurements:}

Body height was measured to the nearest $0.1 \mathrm{~cm}$. Bodyweight was measured with an electronic scale to the nearest $0.1 \mathrm{~kg}$ with participants wearing light clothes and barefooted. Body mass index was calculated based on the body weight in kilograms divided by the square of the body height in meters. Percentiles according to age and sex were defined in the intervals $\mathrm{p} \geq 95-98$ and $\mathrm{p} \geq 99$ (Wohlfahrt-Veje, et al,2014).

\section{Laboratory Investigation:}

\section{Sampling}

Five millimeters $(5 \mathrm{ml})$ of venous blood were withdrawn from every participant by complete aseptic procedures. The blood was collected in plain vacutainer tubes then centrifuged at the speed of $3000 \mathrm{rm}$ for separation 
of serum. The separated serum was kept in special aliquots at $-20{ }^{\circ} \mathrm{C}$ until assaying.

All subjects participating in this study were subjecting to the following laboratory measurements:

\section{Measurement of vitamins A\& $E$ :}

The measurement of these vitamins was done using high -performance liquid chromatography (HPLC) by ultraviolet detector by isocratic separation and C18 columns. Vitamin A ( $\chi$ max) was detected at $325 \mathrm{~nm}$. Vitamin E ( $\chi$ max) was detected at 295 nm., (Greaves et al.2010). Reference range for vitamin $\mathrm{A}$ in serum for children 7-12 years $(12.8-81.2 \mathrm{mcg} / \mathrm{dl})$ according to Ross (2006) and that for vitamin $\mathrm{E}$ for children $0-17$ years: (3.8-18.4 mg/l) according to Traber (2006)

\section{Measurement of vitamin $C$ :}

The concentration of vitamin $\mathrm{C}$ in serum was estimated by the phenylhydrazine spectrophotometry method. Absorbance of sample and standard were read against blank at $520 \mathrm{~nm}$ with spectrophotometry (Karim et al., 2011). Reference range for vitamin $C$ in serum was $(0.6-2 \mathrm{mg} / \mathrm{dl})$ according to (Ball 2004).

\section{RESULTS AND DISSECTION:}

Low socioeconomic status, low birth weight, obesity, urban environment, tobacco smoke exposure, regional or cultural dietary habits in minority subgroups, or dietary modification in families with other members who have asthma or allergy. Table (1) includes these previous parameters plus Maternal and Paternal History of Asthma. The study was included 54 boys (51.9\%) and 50 girls (48.1\%) aged 7-10 years. There were more parents with "senior high school education" than either those with "college education" or those with "less than senior high school education". $16.3 \%$ of mothers and $7 \%$ of fathers of asthmatic cases had a history of asthma, $58.7 \%$ of children had one or more siblings. Asthmatic children were overweight, had a significantly higher BMI $(20.8 \pm 7)$ than normal children (17.3 \pm 5.9$)$, and were more likely to engage in sweating exercise $(32.6 \%)$ than normal individuals (9.8\%). Paternal smoking was significantly higher for asthmatic children parallel normal children.

There is nothing can do about age or family history, there are things can do to reduce risk of asthma, healthy weight and quitting cigarettes are maintained to scale back the severity or frequency of asthma attacks 
and, in some cases, erase those (Garcia-Larsen et al., 2017). Several prospective studies, both within children and adults, indicate that obesity antedates asthma, which the relative risk of incident asthma increases with body mass index (BMI), also appears to worsen asthma control, (Saint-Pierre et al., 2006; Lavoie et al., 2006), some but not all studies indicate that it can increase asthma severity (Beuther and Sutherl 2007; Taylor et al., 2008). Shore, (2007) observed that either surgical or dietinduced weight loss improves many asthma outcomes, provides additional support for a relationship between obesity and asthma, although, in many of those studies, pulmonary function and airway inflammation outcomes were not assessed. Das, (2001) reported that the obesity is also a low-grade systemic inflammatory disease. Overweight and obese of all age have high serum levels of C-reactive protein, interleukin-6, tumor necrosis factoralpha, and leptin, which are known markers of inflammation. Obesity is both a risk factor and a disease modifier of asthma in both children and adults, the commonly approved incontrovertible fact that asthma is an inflammatory process (Freedman et al., 2017). This result of the present study confirms the findings of previous studies that the elevation BMI is associated with a high prevalence of asthma symptoms in children. Camargo et al., (1999) suggested that a rise in BMI of children is associated with a dominance of symptoms that are often attributed to asthma, but not with a higher prevalence of asthma. Chen et al., (2017) explained the mechanisms that link obesity and asthma might include obesity-influenced lung physiology, such as reductions in pulmonary compliance and limitations in airflow, systemic inflammation, dysfunctions of the sympathetic nervous system, and common genetic factors. In addition, children with asthma are known to present with reduced levels of physical activity and may potentially suffer from the side effects of corticosteroid medications that increase their risk of obesity.

In recent years, there has been increasing interest in the role of nutrition in the development of asthma, particularly in developing nations. It has been postulated that changes in diet and nutrition may play a role in promoting its onset. In particular, interest has focused on the intake of antioxidant vitamins, especially vitamins $\mathrm{A}, \mathrm{C}, \mathrm{E}$, and the carotenoids, in the modulation of oxidative lung or airway injury from inflammatory cells. 
Table 2 revealed that the daily intake from vitamin $\mathrm{A}(\mu \mathrm{g} /$ day) and $\mathrm{E}$ ( $\mathrm{mg} /$ day) within asthmatic individuals were lower than normal children with a percentage from RDAs were $101 \%$, $94 \%$, and $86 \%, 79 \%$ receptively, and there were no significant differences between them. Vitamin $\mathrm{C}$ showed a decrease in significant differences $(P=0.022)$ of asthmatic children compared to the normal case. These results were in harmony with a study done by De Luis et al., (2005), who concluded that asthmatic patients have a lower intake of vitamins $\mathrm{A}, \mathrm{C}$, and $\mathrm{E}$ than do non-asthmatic subjects. Ellwood et al., (2001) found that diets rich in antioxidant vitamins (Vitamins $\mathrm{C}, \mathrm{E}$, and $\beta$-carotene) might reduce the susceptibility of the lung to oxidant damage and inflammation. The ways that vitamins $\mathrm{C}$ and $\mathrm{E}$ may help asthmatics include an increase of histamine, rate of reactive oxygen species removal, decrease in the production of bronchoconstrictor inflammatory markers like prostaglandins, and decrease in a contracture of airway smooth muscle cells (Han et al., 2013).

Finding in this study has shown that the risk of childhood asthma increased by fewer levels of serum vitamin $\mathrm{C}$, it was at a beginning of the reference range (Table 3). Low vitamin $\mathrm{C}$ serum levels were predictive of asthma. Vitamins A, E, and C in serum of asthmatic cases were lower than normal children were by $-5,-2.9$, and -11 percent change respectively. The present study was matching with a study done by Seaton and Devereux (2000), who reported that the results were indicated that vitamin $\mathrm{C}$ plays a role in the evolution of asthma. Additionally, the study also investigated the temporal relation between vitamin $\mathrm{C}$ and asthma by examining the effect of serum ascorbic acid on the existence of current asthma. It is an antioxidant present in the airway and alveolar lining fluid. Schock et al., (2001) indicated that vitamin $\mathrm{C}$ could modify oxidative insults from inhaled agents, infectious agents, or cellular inflammation. Consistent with this conclusion is the finding by Romieu et al., (2002) that supplementation with vitamins $\mathrm{C}$ and $\mathrm{E}$ in asthmatic children had a protective effect against high levels of ozone. While supplementation, as a treatment for chronic asthma was inconclusive in the literature review by Kaur et al., (2001). Monteleone and Sherman (1997) have concluded that vitamin C supplementation provides a short-term benefit in treating asthma. Vitamin $\mathrm{E}$ is a peroxyl-radical scavenger that can protect neurons and respiratory 
mucosa from oxidant damage; it can significantly reduce the incidence of asthma and relieve respiratory mucosa inflammation (Yuqing, et al., 2016). Vitamin A is an antioxidant that plays a role in lung development and regeneration of epithelial lung tissue (Checkley et al., 2010). Asthmatic symptoms are associated with airway inflammation, infection, exertion, or stress have appeared within asthmatic children. These factors have been shown to decrease serum retinol levels by increasing cellular demand for retinol and increasing its urinary elimination (Filteau et al., 1993). Airway inflammation in asthmatic patients is associated with increased production of reactive oxygen species (ROS) by peripheral blood eosinophils, neutrophils, and alveolar macrophages (Maier 1993). BCarotene, by quenching singlet oxygen, may reduce airway inflammation in asthma (Burton et al., 1994). The utilization of vitamin $A$ as an antioxidant may be reducing serum vitamin A levels. Hypovitaminosis A induces respiratory epithelial changes, such as metaplasia (Zachman 1994), and may predispose to respiratory infections Bloem et al., 1990), which may exacerbate acute asthmatic attacks in children.

\section{CONCLUSION:}

Despite the low level of intake antioxidants or there in serum within asthmatic children with no significant differences, they showed signs of asthma.

\section{REFERENCES:}

Amanullah I; Khan YH; Anwar I; Gulzar A; Mallhi TH and Raja AA (2019):

Effect of vitamin $\mathrm{E}$ in nonalcoholic fatty liver disease: a systematic review and metaanalysis of randomized controlled trials. Postgrad Med J. 95(1129):601-611

Asher MI; Keil U; Anderson HR; Beasley R; Crane J; Martinez F; Mitchell EA; Pearce N, Sibbald B, Stewart AW; Strachan D; Weiland SK and Williams HC(1995):

International Study of Asthma and Allergies in Childhood (ISAAC): rationale and methods. Eur Respir J. 1995; 8:483-91.

\section{Ball GFM (2004):}

Vitamins: Their Role in the Human Body. London, Blackwell Publishing LTD, pp 393-420 
Beuther DA and Sutherland ER (2007):

Overweight, obesity, and incident asthma: a metaanalysis of prospective epidemiologic studies. Am J Respir Crit Care Med.; 175:661-6.

\section{Bloem MW; Wedel M and Egger RJ (1990):}

Mild vitamin A deficiency and risk of respiratory tract diseases and diarrhea in preschool and schoolchildren in northeastern Thailand. Am J Epidemiology, 131:332-339.

\section{Burton GW and Ingold KU (1994):}

B-Carotene: An unusual type of lipid antioxidant. Science; 224:569573.

Camargo CA; Weiss ST; Zhang S; Willett WC and Speizer FE (1999):

Prospective study of body mass index, weight change, and risk of adult-onset asthma in women. Arch Intern Med.; 159:2582-2588.

Checkley W; West KP; Wise RA; Baldwin MR; Wu L; LeClerq SC; Christian P; Katz J; Tielsch JM; Khatry $S$ and Sommer A (2010):
Maternal vitamin A supplementation and lung function in offspring. $N$ Engl $J$ Med.; 362 (19):1784-94.

Chen Z; Salam MT; Alderete TL; Habre R; Bastain T; Berhane $K$ and Gilliland FD (2017):

Effects of Childhood Asthma on the Development of Obesity among School-aged Children, American Journal of Respiratory and Critical Care Medicine, Volume 195 Number 9, 1181-1188

Cheng P; Wang L; Ning S; Liu Z; Lin H; Chen S and Zhu J (2018):

Vitamin $\mathrm{E}$ intake and risk of stroke: a meta-analysis. $\mathrm{Br} J$ Nutr.; 120(10):1181-1188

\section{Das UN (2001):}

Is obesity an inflammatory condition? Nutrition; 17 (1112):953-66.

de Luis DA; Armentia A; Aller R; Asensio A; Sedano E; Izaola $O$ and Cuellar L(2005):

Dietary intake in patients with asthma: a case control study. Nutrition; 21(3):320-4 
Ellwood P; Asher MI; Björkstén B; Burr M; Pearce N and Robertson CF (2001):

Diet and asthma, allergic rhinoconjunctivitis and atopic eczema symptom prevalence: an ecological analysis of the International Study of Asthma and Allergies in Childhood (ISAAC) data. ISAAC Phase One Study Group. Eur Respir J.; 17(3):436-43.

Federico MI; Hoch HE; Andercon WC; Spahn JD and Szefler SJ (2016):

Asthma Managments for Children: Risk Identification and Prevention // Advances in Pediatrics Vol. 63, Issue 1, p103-126.

Filteau SM; Morris S; Abbott RA; Tomkins AM; Kirkwood BR; Arthur P; Ross DA; Gyapong JO and Raynes JG (1993):

Influence of morbidity on serum retinol of children in a community-based study in northern Ghana. Am J Clin Nutr.; 58:192-197.

Freedman DS; Butte NF; Taveras EM; Goodman AB; Ogden CL and Blanck HM (2017):
The Limitations of Transforming Very High Body Mass Indexes into $\mathrm{z}$-Scores among 8.7 Million 2- to 4Year-Old Children. $J$ Pediatr. 2017; 188:50-6.

Garcia-Larsen V; Arthur R; Potts JF; Howarth PH; Ahlström M; Haahtela T; Loureiro C; Bom AT; Brożek G; Makowska J; Kowalski ML; Thilsing T; Keil T; Matricardi PM; Torén K; Zele TV; Bachert C; Rymarczyk B; Janson C; Forsberg B; Niżankowska-Mogilnicka $E$ and Burney PGJ(2017):

Is fruit and vegetable intake associated with asthma or chronic rhino-sinusitis in European adults? Results from the Global Allergy and Asthma Network of Excellence (GA2LEN) Survey. Clin Transl Allergy.;7: 3.

Gibson R S (1990):

Principals of nutritional assessment. Oxford University Press. New York, Oxford.

Global Initiative for Asthma (GINA) (2017):

Global strategy for asthma management and prevention. Updated 2017. 


\section{Global Initiative for Asthma (GINA)} (2019):

Pocket guide for asthma management and prevention. pp. $1-32$.

Greaves R; Jolly L; Woollard G and Hoad K (2010):

Serum vitamin $A$ and $E$ analysis: comparison of methods between laboratories enrolled in an external quality assurance program. Ann Clin Biochem ; 47:78.

Hacışevki A (2009:

An overview of ascorbic acid biochemistry. Journal of Faculty of Pharmacy, 9; 38(3):233-255

\section{Han Y-Y; Blatter J; Brehm JM;} Forno E; Litonjua AA and Celedón JC (2013):

Diet and asthma: vitamins and methyl donors. Lancet.; 1 (10):813-822.

Heine G; Hollstein T; Treptow S; Radbruch $A$ and Worm $M$ (2018):

9-cis retinoic acid modulates the type I allergic immune response. $J$ Allergy Clin

Immunol; 141:650-658

Huang Z; Liu Y; Qi G; Brand D and Zheng S (2018):

Role of Vitamin A in the Immune System. J Clin Med; 7:258.

Hu N; Li Q-B and Zou S-Y (2018):

.Effect of vitamin $A$ as an adjuvant therapy for pneumonia in children: a Metaanalysis]. Zhongguo Dang Dai Er Ke Za Zhi; 20:146-53.

Karim R; Nader Z; Islam M; Ahmed M; Mustafa A; SHohag H; Al Maruf A and Abul Hasnat (2011) :

Serum MDA and vitamin $\mathrm{C}$ in conversion disorder patients. Dhaka Univ. J. Pharm. Sci. 10(1): 59- 64 .

Kaur B; Rowe BH and Ram FS (2001):

Vitamin C supplementation for asthma. Cochrane Database Syst Rev.;(4):CDC000993.

Kiser PD; Golczak $M$ and Palczewski K (2014):

Chemistry of the Retinoid (Visual) Cycle. Chem Rev; 114:194-232. 
Kojo S (2004):

Vitamin C: basic metabolism and its function as an index of oxidative stress. Curr Med Chem. 2004; 11:1041-64.

Lavoie KL; Bacon SL; Labrecque M; Cartier A and Ditto B (2006):

Higher BMI is associated with worse asthma control and quality of life but not asthma severity. Respir Med; 100:64857.

\section{Maier K (1993):}

How the lung deals with oxidants. Eur Respir J.; 6:334336.

\section{Monteleone CA and Sherman AR} (1997):

Nutrition and asthma. Arch Intern Med; 157:23-34.

\section{Moreno-Macias $\mathrm{H}$ and Romieu I (2014): \\ Effects of antioxidant supplements and nutrients on patients with asthma and allergies. $J$ Allergy Clin Immunol.; 133(5):1237-44, quiz 1245.}

National Nutrition Institute (NNI) (2006):
Food consumption pattern and nutrients intake among different population groups. $2^{\text {ed }}$ edition Supported by WHO/EMRO.

\section{Pantazi E; Marks E; Stolarczyk E; Lycke N; Noelle RJ and Elgueta R (2015): \\ Cutting Edge: Retinoic Acid Signaling in B Cells Is Essential for Oral Immunization and Microflora Composition. J Immunol; 195:1368- 71 .}

\section{Pedersen S; Reddel H and Boulet LP (2018): \\ Global initiative for asthma, Pocket guide for asthma management and prevention for adults and children older than 5 years.}

Rizvi S; Raza ST; Ahmed F; Ahmad A; Abbas S and Mahdi F (2014):

The Role of Vitamin E in Human Health and Some Diseases, Sultan Qaboos University Med J, Vol. 14, Iss. 2, pp. e157-165,

Rock E; Winklhofer-Roob BM; Ribalta J; Scotter M; Vasson MP; 
Brtko J; Brigelius-Flohe R; Bronner $A$ and Azais-Braesco V (2001):

Vitamin A, vitamin $\mathrm{E}$ and carotenoid status and metabolism during ageing: functional and nutritional consequences (VITAGE PROJECT). Nutr Metab Cardiovasc; 11:70-73.

Romieu I; Sienra-Monge JJ; Ramírez-Aguilar M; Téllez-Rojo MM; Moreno-Macías H; ReyesRuiz NI; del Río-Navarro BE; RuizNavarro MX; Hatch G; Slade R and Hernández-Avila M (2002);

Antioxidant supplementation and lung functions among children with asthma exposed to high levels of air pollutants. Am J Respir Crit Care Med. 1;166(5):703-9.

Ross AC (2006):

Vitamin A and Carotenoids. In Modern Nutrition in Health and Disease. $10^{\text {th }}$ edition. Edited by ME Shils, M Shike, AC Ross, et al. Philadelphia, Lippincott Williams and Wilkins, pp 351375

Saint-Pierre P; Bourdin A; Chanez P; Daures JP and Godard P (2006):
Are overweight asthmatics more difficult to control? Allergy; 61:79-84

Schlueter AK and Johnston CS (2011):

Vitamin C: Overview and Update, Journal of EvidenceBased Complementary \& Alternative Medicine; 16(1) 49-57

Schock BC; Young IS; Brown V; Fitch PS; Taylor R; Shields MD and Ennis M (2001):

Antioxidants and protein carbonyls in bronchoalveolar lavage fluid of children: normal data. Pediatr Res.; 49(2):15561.

Seaton A and Devereux G (2000):

Diet, infection and wheezy illness: lessons from adults. Pediatr Allergy Immunol; (suppl. 13):37-40.

Seo G-Y; Leea J-M; Jang Y-S; Kang SG; Yoon S; Ko H-J; LeeG-S; Park S-R; Nagler CR and Kim P-H (2017):

Mechanism underlying the suppressor activity of retinoic acid on IL4-induced IgE synthesis and its physiological implication. Cell Immunol; 322:49- 55 . 
Shanmugasundaram KR; Kumar SS and Rajajee $S$ (2001):

Excessive free radical generation in the blood of children suff erring from asthma. Clin Chim Acta; 305:107-114.

\section{Shmarakov IO; Yuen JJ and Blaner WS (2013): \\ Carotenoid Metabolism and Enzymology. Carotenoids Hum. Heal. Totowa, NJ: Humana Press; 2013, p. 29-56.}

Shore SA (2007):

Obesity and asthma: lessons from animal models. $J$ Appl Physiol.; 102:516-28.

Taylor B; Mannino D; Brown C; Crocker D; Twum-Baah $\mathrm{N}$ and Holguin F (2008):

Body mass index and asthma severity in the National Asthma Survey. Thorax; 63:14-20.

Traber MG (2006):

Vitamin E. In Modern Nutrition in Health and Disease.10th edition. Edited by ME Shils, M Shike, AC Ross, et al. Philadelphia, Lippincott
Williams and Wilkins, pp 434441

Wohlfahrt-Veje C; Tinggaard J;
Winther K; Mouritsen A; Hagen
CP; Mieritz MG; de Renzy-Martin
KT; Boas M; Petersen JH and Main
KM (2014):
Body fat throughout childhood
in 2647 healthy Danish
children: agreement of BMI,
waist circumference, skinfolds
with dual X-ray
absorptiometry. Eur J Clin
Nutr.; 68(6):664-70.

Yuqing Zhu; Jinquan Li; Zhuo Wu; Yu Lu; Huihui You; Rui Li, Baizhan Li; Xu Yang and Liju Duan (2016):

Acute exposure of ozone induced pulmonary injury and the protective role of vitamin $\mathrm{E}$ through the Nrf2 pathway in Balb/c mice. Toxicol Res.; 5(1):268-77.

Zachman RD (1994):

Role of vitamin A in lung development. $J \quad$ Nutr; 125:1634S-1638S.

Zingg JM (2015):

Vitamin E: a role in signal transduction. Annu. Rev. Nutr. 35, 135-173. 


\section{Table (1): Basic Characteristics of the Study Population}

\begin{tabular}{|c|c|c|c|}
\hline \multicolumn{2}{|l|}{ Variables } & \multirow{2}{*}{$\begin{array}{l}\text { Normal } \\
\mathrm{N}=61\end{array}$} & \multirow{2}{*}{$\begin{array}{l}\text { Asthmatic } \\
\text { Individuals } \\
\mathrm{N}=43 \\
\mathrm{~N}(\%) \\
\text { or Mean } \pm \mathrm{SD} \\
\end{array}$} \\
\hline & & & \\
\hline Age & Years & $7-10$ & $7-10$ \\
\hline \multirow{2}{*}{ Sex } & Boys & $29(47.5)$ & $25(58.1)$ \\
\hline & Girls & $32(52.5)$ & $18(41.9)$ \\
\hline$\overline{\text { BMI }}$ & $\mathrm{Kg} / \mathrm{m}^{2}$ & $17.3 \pm 5.9$ & $20.8 \pm 7$ \\
\hline \multirow{2}{*}{ History of Food allergy } & Yes & $17(27.9)$ & $9(20.9)$ \\
\hline & No & $44(72.1)$ & $34(79.1)$ \\
\hline \multirow{2}{*}{ No. of siblings } & 1 & $25(41)$ & $18(41.9)$ \\
\hline & $>2$ & $36(59)$ & $25(58.1)$ \\
\hline \multirow{2}{*}{ Maternal Smoking } & Yes & 4 & $4(9.5)$ \\
\hline & No & $57(93.4)$ & $39(90.5)$ \\
\hline \multirow{2}{*}{ Paternal Smoking } & Yes & $20(32.8)$ & $21(48.8)$ \\
\hline & No & $41(67.2)$ & $22(51.2)$ \\
\hline \multirow{2}{*}{$\begin{array}{lll}\text { Maternal History } & \text { of } \\
\text { Asthma } & & \\
\end{array}$} & Yes & $8(13.1)$ & $7(16.3)$ \\
\hline & No & $53(86.9)$ & $36(83.7)$ \\
\hline \multirow{2}{*}{$\begin{array}{lll}\text { Paternal } & \text { History } & \text { of } \\
\text { Asthma } & & \\
\end{array}$} & Yes & $3(4.90)$ & $3(7.1)$ \\
\hline & No & $58(95.1)$ & $40(92.9)$ \\
\hline \multirow{2}{*}{$\begin{array}{l}\text { Vigorous exercise }>3 / \\
\text { week }\end{array}$} & Yes & $6(9.8 \%)$ & $14(32.6 \%)$ \\
\hline & No & $55(90.2)$ & $29(67.4)$ \\
\hline \multirow{4}{*}{ Maternal Education } & Illiterate & $14(23.3)$ & $6(14)$ \\
\hline & Primary, Prep & $11(18.3)$ & $6(14)$ \\
\hline & Secondary, Intermediate & $25(41.7)$ & $24(55.8)$ \\
\hline & University & $10(16.7)$ & $7(16.3)$ \\
\hline \multirow{4}{*}{ Paternal Education } & Illiterate & $12(20)$ & $4(9.3)$ \\
\hline & Primary, Prep & $10(16.7)$ & $6(14)$ \\
\hline & Secondary, Intermediate & $28(46.7)$ & $26(60.5)$ \\
\hline & University & $11(16.7)$ & $7(16.3)$ \\
\hline
\end{tabular}


Table (2): Daily Nutrient Intake of some Antioxidant Vitamins in the Study Group (mean \pm SD)

\begin{tabular}{|c|c|c|c|}
\hline $\begin{array}{l}\text { Group } \\
\text { Vitamins }\end{array}$ & $\begin{array}{l}\text { Normal cases } \\
(n=61)\end{array}$ & $\begin{array}{l}\text { Asthmatic } \\
\text { Individuals } \\
(\mathrm{n}=43)\end{array}$ & $\begin{array}{l}P \\
\text { value }\end{array}$ \\
\hline $\begin{array}{l}\text { Vitamin A ( } \mu \mathrm{g} / \\
\text { day) }\end{array}$ & $504.9 \pm 112.6$ & $470.9 \pm 103.9$ & \multirow{3}{*}{0.319} \\
\hline RDAs & \multicolumn{2}{|c|}{$500 \mu g / d a y$} & \\
\hline \% from RDA & $101 \%$ & $94 \%$ & \\
\hline $\begin{array}{l}\text { Vitamin E (mg / } \\
\text { day) }\end{array}$ & $7.75 \pm 2.39$ & $7.09 \pm 2.24$ & \multirow{3}{*}{0.904} \\
\hline RDAs & \multicolumn{2}{|c|}{$9 \mathrm{mg} / \mathrm{day}$} & \\
\hline \% from RDA & $86 \%$ & $79 \%$ & \\
\hline $\begin{array}{l}\text { Vitamin C (mg / } \\
\text { day) }\end{array}$ & $30.09 \pm 2.84$ & $25.51 \pm 4.10$ & \multirow{3}{*}{$0.022 *$} \\
\hline RDAs & \multicolumn{2}{|c|}{35 mg/day } & \\
\hline$\%$ from RDA & $86 \%$ & $73 \%$ & \\
\hline
\end{tabular}

Vitamin. $E *$ Adequate Intake (AI) from National Institutes of health 
Table (3): Serum Level of Antioxidant Vitamins in the Study Group (Mean \pm SD)

\begin{tabular}{|c|c|c|c|c|}
\hline $\begin{array}{l}\text { Group } \\
\text { Vitamins }\end{array}$ & Normal range & $\begin{array}{l}\text { Normal cases } \\
(\mathrm{n}=61)\end{array}$ & $\begin{array}{l}\text { Asthmatic } \\
\text { Individuals } \\
(n=43)\end{array}$ & $P$ value \\
\hline $\begin{array}{l}\text { Vitamin A }(\mu \mathrm{g} / \\
\mathrm{dl})\end{array}$ & \multirow{2}{*}{$\begin{array}{c}12.8-81.2 \\
\mathrm{mcg} / \mathrm{dl}\end{array}$} & $84.7 \pm 40.6$ & $80.4 \pm 51.7$ & \multirow{2}{*}{0.902} \\
\hline $\begin{array}{l}\% \text { change vs } \\
\text { normal case }\end{array}$ & & - & $-5 \%$ & \\
\hline $\begin{array}{ll}\text { Vitamin } \\
(\mathrm{mg} / \mathrm{l})\end{array} \quad \mathrm{E}$ & \multirow{2}{*}{$3.8-18.4 \mathrm{mg} / \mathrm{l}$} & $13.6 \pm 5.2$ & $13.2 \pm 6.1$ & \multirow{2}{*}{0.793} \\
\hline $\begin{array}{l}\% \text { change vs } \\
\text { normal case }\end{array}$ & & - & $-2.9 \%$ & \\
\hline $\begin{array}{l}\text { Vitamin } \\
\mathrm{C}(\mathrm{mg} / \mathrm{dl})\end{array}$ & \multirow{2}{*}{$0.6-2 \mathrm{mg} / \mathrm{dl}$} & $0.76 \pm 0.38$ & $0.63 \pm 0.58$ & \multirow{2}{*}{0.417} \\
\hline $\begin{array}{l}\% \text { change vs } \\
\text { normal case }\end{array}$ & & - & $-11 \%$ & \\
\hline
\end{tabular}

Significant $P \leq 0.05$ 


\section{التأثير المحتمل لتناول فيتامينات أ،جهـه ومستوياتها في مصل الدم لاى الاطفال المصابين بالريو

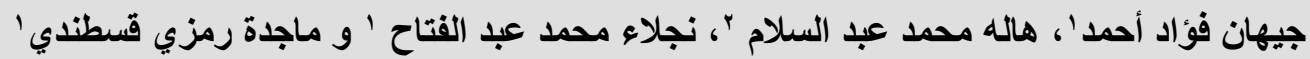

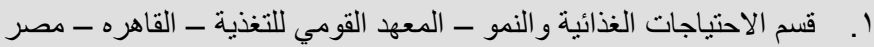

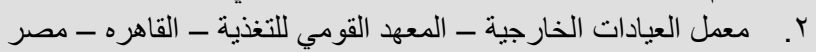

مرض حساسية الجهاز التنفسي هو حالة التهاب مصدوبة بالاجهاد التأكسدي . قد يكون ليضادات الاكسدة

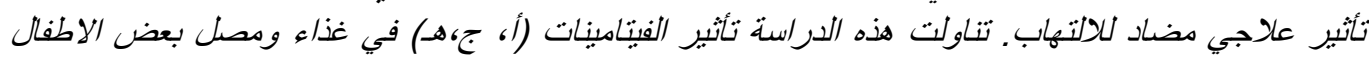

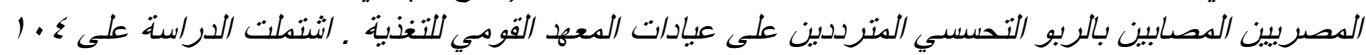

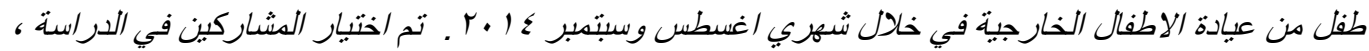

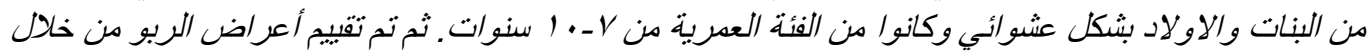

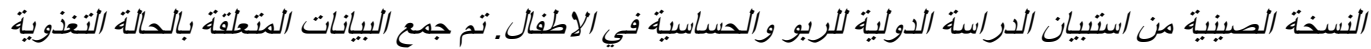

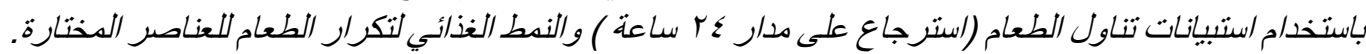

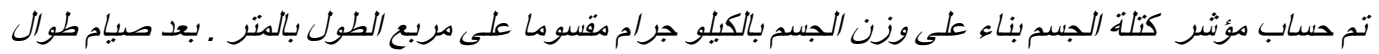

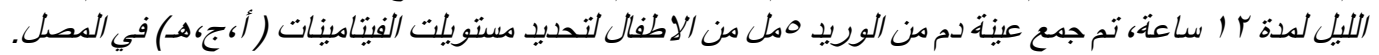

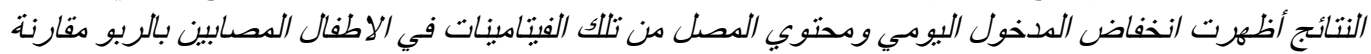

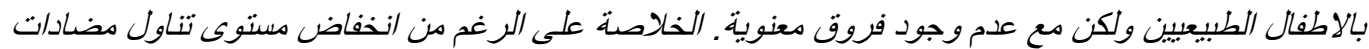

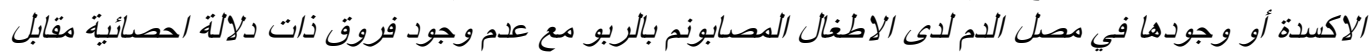

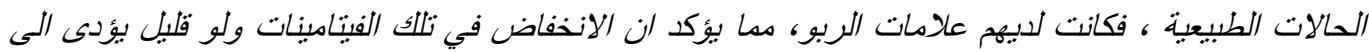
الكلمات المفتاحية: مضاد/ت الاكسدة - الربو - الاطفال 